\title{
Sustainability assessment of biodiesel produced from Jatropha curcas using life cycle assessment approach
}

Vijay Thakur and Munish K. Chandel*, Environmental Science and Engineering Department, IIT Bombay

*Environmental Science and Engineering Department, IIT Bombay, Mumbai, Emailmunish.chandel@iitb.ac.in

Transport sector in India is heavily dependent on fossil fuels and $\sim 75 \%$ of the demand is met by import. National Biofuel Policy, 2009 focused on production of biodiesel from non-edible oil seeds. We assessed the sustainability of biodiesel produced from Jatropha curcas, using the life cycle assessment approach. India specific inventory data for biodiesel production was collected by extensive literature review. GaBi software was used to model the life cycle of biodiesel. The environmental impacts are compared for different blends of biodiesel with reference to diesel in four impact categories: Global Warming Potential, Acidification Potential, Eutrophication Potential, and Human Toxicity Potential. Using the biodiesel may reduce the global warming potential by $64.6 \%$ as compared to fossil diesel; while eutrophication potential, acidification potential, and human toxicity potential impacts may increase by $61.3 \%, 36.5 \%$, and $52.5 \%$ respectively. A trade-off between impact categories is seen for biodiesel. Sensitivity analysis was done to identify most sensitive parameters in biodiesel life cycle. Use of electricity, life cycle span of Jatropha, seed yield, methanol, urea fertilizer, NOx emission factor, and steam are found to be highly sensitive in biodiesel life cycle. Scenario analysis was done to analyse the effect of change in seed yield, life span, and emission intensity of Indian electricity grid. Even low yield of Jatropha provides reduction in global warming potential $(\sim 27.7 \%)$ but in other impact categories significant increase is expected. Impacts could be further minimized if the emissions from grid are minimized in future.

\section{Keywords}

Life cycle assessment, Biodiesel, Jatropha curcas, Sensitivity analysis, Global Warming Potential, 


\section{Introduction}

Over the past century, automobile sector has been revolutionized and benefitted the humans by giving quick access to goods, services and personal mobility. With improving lifestyle and growing per capita income, number of vehicles likewise increase accordingly which are great concern in perspective of environment. In India, transport sector is heavily dependent on fossil fuels and meets $75-80 \%$ of its total oil requirements through import. The estimates show that the share of import energy will surpass $90 \%$ by 2030 [1]. Burning of fossil fuels also emits harmful air pollutants and greenhouse gases which includes Carbon dioxide $\left(\mathrm{CO}_{2}\right)$, Carbon Monoxide $(\mathrm{CO})$, Nitrogen Oxides $\left(\mathrm{NO}_{\mathrm{x}}\right)$, Sulphur Oxides $\left(\mathrm{SO}_{\mathrm{x}}\right)$, Volatile Organic Carbons (VOCs) and Particulate matters (PM). Indian transport sector emitted 258.10 million tonnes of $\mathrm{CO}_{2}$ in 2003-2004 and road transport contributed $94.5 \%$ of the total transport emissions [2].

A switch towards environment friendly alternative fuels will solve the problem of growing concern about climate change, and energy security. Commercially available alternative fuels are biodiesel, bioethanol, and electricity. Biodiesel are clean burning mono-alkyl ester based oxygenated fuels produced from various feedstocks such as soybean, mustard, rapeseed, palm, and sunflower oil in many parts of the world (Agarwal 2007). However, for country like India, food security is the prime concern and India imports 40-50\% of the vegetable oil for domestic needs, so most of these options are not viable in Indian scenario [3]. Jatropha oil is non-edible oil, it avoids the food versus fuel dilemma and is a preferred feedstock for biodiesel production in India $[4,5,6]$. Jatropha as a feedstock for biodiesel in India was also supported by National Biodiesel Mission (2009) and studies have confirmed that around 40-50\% of biodiesel can be used in current combustion engine without any major modification $[4,7,8]$. By-products from biodiesel production like seed cake are rich in nitrogen and can be used as fertilizer $[9,10]$. Though Jatropha can survive in dry lands too, but proper irrigation and application of fertilizer is required in initial years to obtain good yield [6]. Cultivation of Jatropha provides the advantage of using wastelands and simultaneously producing useful biodiesel which can be used in today's vehicle fleet easily. 10- 63 million hectare of such wasteland is reported to be available in India which can be used for Jatropha cultivation $[4,11]$

Many LCA studies published on Jatropha has not considered the combustion phase. However, from the life cycle perspective it is important to consider the complete life cycle of a product for doing an apple to apple comparison between Jatropha and the fossil fuel diesel. Only few studies are there where a complete Cradle to Grave comparison is done, and in these studies mostly GWP has been used as a single parameter to compare the biodiesel and diesel. Choosing 
$\mathrm{GWP} / \mathrm{CO}_{2}$ emissions a single parameter for comparison give bias towards the biofuel as they are carbon neutral, therefore it is important to consider the other environmental impact categories as well. Study by Achten et al. [12] has considered GWP, AP, EP, and Net Energy Ratio as the parameter to assess the biodiesel, however the system considered had less fertilizer inputs. Pandey et al. [6] calculated the life cycle impacts of biodiesel production by taking average yield of 5 years as 4.52 ton of seeds per hectare, which included consideration of very high yields in fourth (7500 kg seeds/ha) and fifth (11250 kg seeds/ha) year. It is experienced that after fertilizer application and irrigation the average yields of Jatropha seeds over its life cycle are about 1.4-2 ton/ha [12, 13, 14].Montobibo et al. [15] and Axelsson et al. [16] reported the average yield even below $1000 \mathrm{~kg} / \mathrm{ha}$ after interviewing the farmers. Study by Kumar et al. [17] has also considered a very high value of seed yield which was 5.9-ton seeds/ha under irrigation condition and considered only GWP and net energy ratio. Study by Whitaker and Heath (2009) also considered only the GWP and net energy ratio. This study shows the cradle to grave environmental impacts of Jatropha biodiesel in four major environmental impact categories and compare it with the reference fuel diesel: Global Warming Potential, Acidification Potential, Eutrophication Potential, and Human Toxicity Potential.

\section{Methods}

Life cycle assessment (LCA) approach is used in the study. The life cycle impact assessment (LCIA) was done in 'GaBi 6.3 Software' using the CML 2015 method. Life cycle plan were prepared for different blends of biodiesel (B5: 5\% biodiesel, B10: 10\% biodiesel, B15: 15\% biodiesel, and B100: 100\% biodiesel) and fossil fuel diesel. In process of biodiesel production, glycerine is also produced which is a valuable by-product. ISO standard says allocation is required when two or more valuable product results from the single process. As the amount of glycerine produced is very less comparing to the biodiesel produced but its economic value ( $60 \mathrm{INR} / \mathrm{L})$ is much higher than the biodiesel ( 37.64 INR/L) [18]; allocation has been done on the price basis for the glycerine and biodiesel. To identify the most sensitive parameters in the life cycle of biodiesel sensitivity analysis is done for B100 blend of biodiesel, total 23 parameters were identified, and value of each parameter was changed by $\pm 10 \%$ and $\%$ change in the life cycle impact was observed. Several scenarios are analysed in the study for three identified highly sensitive parameters: seed yield, life cycle span of Jatropha cultivation, and emission intensity of Indian power grid.

\subsection{Goal and scope definition}


The main objective of this study was to compare the cradle to grave life cycle environmental impacts of biodiesel produced from Jatropha and fossil fuel diesel. The secondary aim was to prepare a complete inventory dataset of input materials used in biodiesel production and their emission factors. Earlier studies have considered the functional unit as $1 \mathrm{~kg}$ or 1 litre of biodiesel production, and some has taken $1 \mathrm{MJ}$ of energy from biodiesel because the scope of the study was limited from cradle to gate. However, as the scope of this study is cradle to grave system boundary it was important to select the functional unit in such a way that it is not biased towards biodiesel or reference fuel diesel. Taking $\mathrm{kg}$ or litre will bias the results towards diesel as it has more energy content comparing to biodiesel, similarly MJ cannot be justified as efficiency of engine for biodiesel is less. As the functional of a fuel is to run the vehicle, we have selected the functional unit to be ' $1000 \mathrm{~km}$ travel distance by a passenger car using biodiesel/diesel' for avoiding the bias. It is assumed that diesel and biodiesel both will be used to run a Bharat Stage IV diesel car which has claimed mileage of $27.62 \mathrm{~km} / \mathrm{L}$ [19]. Primary data for this study is collected from literature and reports, and the background data is used from the GaBi 6.3 software. In the evaluation, environmental impacts from secondary missions which occurs due to infrastructure development etc. are not accounted. System boundary for biodiesel production include Jatropha cultivation, transport to the oil extraction site, oil extraction, oil processing, transport of biodiesel to the retailer, and combustion in vehicle as shown in Figure 1. Inventory data for this study is collected from the extensive review of Indian specific literature and reports. Emission factors for the raw material used are where possible taken from the Indian specific literature sources, in case of non-availability of Indian specific data, global emission factor or GaBi database emission factor are considered.

\subsection{Inventory analysis}

\subsubsection{Cultivation phase}

Cultivation phase include field preparation, fertilizer application, irrigation, and harvesting of Jatropha Seeds. Yield from Jatropha are very low in initial years, it starts giving significant yield from the third year of growth. Yield from Jatropha is obtained in form of fruits, which contains seeds inside it therefore decortication of seeds is required. Decorticated seed represent $60 \%$ of the mass fraction of original corticated seeds [6]. As the life expectancy of Jatropha is $40-50$ years, we assume life cycle of 20 years for the calculation $[12,14]$. The impact from the inputs which are provided only once during initial years are normalized for the entire life cycle of 20 years while calculating the impacts. For example, inputs like urea for nursery, polybags, 
and diesel for tilling of field will be applied once in the entire life cycle. Similarly, fertilizer application and irrigation will be done for initial three years; after that seedcake produced from oil extraction phase will be used as fertilizer. Seed yield of Jatropha is assumed to be 2363 $\mathrm{kg} / \mathrm{ha}$ which is equivalent to $1418 \mathrm{~kg} / \mathrm{ha}$ decorticated seeds [14]. All the input/output parameters data for cultivation phase is given in Table 1.

\subsubsection{Transport to oil extraction site}

After manual harvesting of Jatropha seeds, they are transported to oil extraction site. Distance from cultivation site to oil extraction plant is assumed to be $100 \mathrm{~km}$, and it is assumed that transport will be done by Bharat Stage-IV truck having payload capacity of 12.5 tons. Environmental impacts from transport are calculated based on data available in GaBi software for Indian conditions.

\subsubsection{Oil extraction from Jatropha seeds}

After transportation seeds are first decorticated with the help of a decorticator. $40 \%$ weight reduction of seeds occurs after decortication and biomass thus left is fruit shell or husk which can be used as energy source (Pandey et al. 2011). Input/output parameters data for oil extraction phase is given in Table 2 .

\subsubsection{Oil processing (transesterification) phase}

Oil obtained has high viscosity and is not suitable for use in diesel engine; transesterification is the process by which triglycerides of oil are converted into methyl esters. Transesterification of the Jatropha oil is done using catalyst and alcohol, $\mathrm{NaOH}$ and methanol are used as catalyst and alcohol in most of the studied literature. Input/output parameters data for transesterification phase is given in Table 3.

\subsubsection{Transport of final product to retailer}

Distance from biodiesel plant to the retailer is assumed to be $100 \mathrm{~km}$, and it is assumed that transport will be done by truck with Bharat Stage IV emission standards and having payload capacity of 18 tons.

\subsubsection{Combustion phase}

Different blends of biodiesel (B5, B10, B15, and B100) and reference fuel diesel are assumed to be used in a diesel vehicle with claimed mileage of $27.6 \mathrm{~km} / \mathrm{L}$ (MS 2016). We assume actual on road mileage of $70 \%$ of the claimed mileage for our calculation [22]. Emission factors for diesel vehicle are taken from a report by Centre Pollution Control Board of India [23]. Emission 
factor for different blends of biodiesel are scaled based on a report published by Air Quality Expert Group [24].

When biodiesel is blended with diesel up to B20 levels, there is less than $2 \%$ change in fuel energy content which has no noticeable change in mileage or economy [20, 25, 26, 27]. Therefore, we assume that B5, B10, and B15 blends will have same mileage as of diesel. In case of pure biodiesel, a decrease of 10\% in fuel economy is expected [26]. All these factors and change in emission factors are considered while calculating the environmental impacts. Emission factors for all flows considered in system boundary are given in Table 6 .

\section{Results and discussion}

\subsection{Environmental impacts for different blends of biodiesel}

Environmental impacts of different biodiesel blends and fossil diesel are shown in Figure 2. Biodiesel has less global warming potential comparing to diesel. However, impact is seen to be increased in other environmental impact categories. Biodiesel (B100) would achieve reduction of $64.6 \%$ in GWP impact; however, AP, EP, and HTP impacts would increase by $31.6 \%, 61 \%$, and 54.6\%, correspondingly. GWP impacts reduction from B100 ( 64.6\%) calculated in this study are like as reported by Whitaker and Heath (2009) 62\% and Achten et al. (2010) $\sim 55 \pm 16 \%$. Except for GWP, it is observed that use of biodiesel will increase the life cycle environmental impacts. Though biodiesel is cleaner fuel while considering combustion phase only; but use of chemicals, fertilizers, fossil fuels, electricity in its early stages of life cycle results in increased AP, EP, and HTP. Also, biodiesel has higher NOx emissions during combustion phase.

\subsection{Contribution of life cycle stages in life cycle environmental impacts from B100}

For B100 fuel, the oil extraction phase is the largest contributor in AP, GWP, and HTP impact categories, while combustion phase is the largest contributor in EP impact category. The cultivation phase shows low contribution in overall life cycle which is contradictory to the results obtained in previous studies $[12,13,17]$. This is because most of the earlier studies has evaluated the initial 1-5 years but in this study life span of 20 years is considered so the impact from the cultivation phase has been normalized. In oil extraction phase, majority of the impact is due to electricity use as Indian electricity grid mix is GHG intensive.

\subsection{Sensitivity analysis:}

For diesel life cycle, six parameters were identified and value of each was varied $\pm 10 \%$. It was observed that $\mathrm{CO}_{2}$ emission factor of diesel is the highest sensitive parameter in GWP impact 
category, while NOx emission factor of diesel was most sensitive parameter in AP, EP, and HTP impact category (Table 7). Distance from refinery had very low effect on the life cycle impact.

For B100 fuel life cycle, total 23 parameters were identified and value of each was varied $\pm 10 \%$. It is observed that the parameters: electricity use, life cycle span, seed yield, methanol use, urea fertilizer use, NOx emission factor, and steam use are highly sensitive. While the parameters like diesel use in irrigation and cultivation, hexane use in solvent extraction, $\mathrm{P}_{2} \mathrm{O}_{5}$ and $\mathrm{K}_{2} \mathrm{O}$ fertilizer use in cultivation, $\mathrm{NaOH}$ used in transesterification, transport distance, $\mathrm{CO}$ emission factor, $\mathrm{CO}_{2}$ emission factor, $\mathrm{PM}$ emission factor, and hydrocarbon emission factor are significantly less sensitive to the life cycle environmental impacts of B100 (Table 8). Values taken for electricity use, methanol use, steam use, NOx emission factor for biodiesel, and fertilizer use are almost same in studied literature. However, there is high uncertainty over the values taken for seed yield, and life cycle span; therefore, several scenarios are analysed for parameters: seed yield and life cycle span of Jatropha. Scenario analysis is also done for the Electricity parameter as it is observed to be highly sensitive and it is expected that emission intensity of Indian power grid will decrease in coming decades due to expected increase in share of renewable energy.

\subsection{Scenario analysis for B100 life cycle plan}

To understand the effect of change in life cycle span, seed yield, and electricity emission intensity on the life cycle environmental impacts from biodiesel over reference fuel diesel, scenario analysis was done. If we evaluate the environmental impacts of biodiesel over the oneyear life cycle span system boundary, GWP impact would reduce by only $2.2 \%$ while AP, EP, and HTP impacts would increase by $115 \%, 215.6 \%$, and $101.8 \%$ respectively (Table 9). From 20 years life cycle span scenario to 8 years life cycle span scenario, there is a gradual increase in environmental impacts, however beyond decreasing life cycle span from 8 years significant increase in environmental impacts can be seen. This is mainly due to the domination of impacts coming from cultivation phase. So, if a biodiesel plant is in operation for at least 8-12 years then only significant reduction in global warming potential can be achieved, however significant increase in other environmental impact category will still occur. Similar results were reported by Achten et al. [12] that $49 \%$ increase in AP, and $430 \%$ increase in EP is expected, which confirms the findings that environmental impacts in other impact category will increase from using biodiesel produced from Jatropha. 
For the Jatropha seed yield three scenarios are considered: scenario 1 (worst case scenario i.e. lowest seed yield reported in literature), scenario 2 (base case scenario i.e. current assumption in study), and scenario 3 (best case scenario i.e. best seed yield reported in literature). For worst case scenario seed yield is taken to be $450 \mathrm{~kg} / \mathrm{ha}$ [15], for base case seed yield is $2363 \mathrm{~kg} / \mathrm{ha}$, and for the best-case scenario seed yield is taken to be 5.9 ton/ha [17]. In case of scenario 1 even at low seed yield Jatropha would reduce GWP impact considerably ( 27.62\%), however environmental impacts will increase significantly in other impact categories. Environmental impacts are increased because with decrease in seed yield more land and plants will be required for production of same amount of biodiesel. In case of scenario 3 (best case scenario), high seed yield of $5900 \mathrm{~kg} / \mathrm{ha}$ would lead to significant reduction in global warming potential and eutrophication potential over base case scenario, however, acidification potential and human toxicity potential will reduce very less over base case scenario (Table 10).

As shown in Table 10, oil extraction phase is the major contributor of life cycle environmental impacts of B100 fuel, and majority of the impacts in oil extraction phase are due to the use of electricity from Indian power grid. Indian power grid is presently dominated by fossil feedstocks $(\sim 80 \%)$ with renewable having less $(\sim 20 \%)$ share in grid electricity [31]. In near future, it is expected that renewable will have significant share in electricity generation so that the environmental impacts intensity of power grid will reduce, so we assume three scenarios: base case scenario (Scenario 1), 15\% reduction in grid intensity (Scenario 2), 30\% reduction in grid intensity (Scenario 3). It is observed that for scenario 2, global warming potential will be reduced by $4.3 \%$ over base case scenario and compared to the reference fuel diesel reduction in GWP impact category will increase from $59.6 \%$ to $61.4 \%$. Significant reduction is expected in acidification potential $(\sim 8.8 \%)$ and human toxicity potential impact category $(\sim 12.6 \%)$ from the base case under scenario 2. For scenario 3, global warming potential will reduce by $9 \%$ over base case scenario (\% saving in GWP over reference fuel diesel will increase from $59.6 \%$ to $63.1 \%$ over base case). Similarly, acidification potential, human toxicity potential, and eutrophication potential will decrease by $19.4 \%, 28.8 \%$, and $6.53 \%$ respectively from the base case scenario (Table 11).

\section{Conclusions}

Life cycle impact assessment of biodiesel production for Indian conditions from Jatropha curcas as feedstock shows that the biodiesel (with considering allocation) can reduce global 
warming potential by as much as $64.6 \%$ in GWP impact category; However, AP, EP, and HTP impacts can increase by $36.5 \%, 61.3 \%$, and $52.5 \%$ respectively. Environmental impacts could be further minimized if the environmental impact intensity of Indian power grid is reduced in near future as electricity is a major contributor in life cycle impacts of biodiesel. The impacts from the biodiesel are majorly from oil extraction and transesterification phase in the life cycle, which are due to the use of natural gas for steam and electricity use in these stages of life cycle. Most of the eutrophication potential impacts are from combustion phase majorly because of $\mathrm{NO}_{\mathrm{X}}$ emissions. If 1- or 2-year life cycle span of the biodiesel plant is considered than environmental impacts will be much higher than the reference fuel diesel, but if the life cycle span of more than 8 years is considered than significant reduction in global warming impacts can be achieved. However still eutrophication, acidification potential, and human toxicity potential impacts are expected to remain on higher side than the reference fuel diesel. It is observed that even low yield of Jatropha i.e. $450 \mathrm{~kg} / \mathrm{ha}$ can reduce the global warming potential $(\sim 27.7 \%)$ but it will increase the impact in other impact categories. Findings of the study shows that biodiesel has the potential of reducing the GWP impact as reported by earlier studies, however it will increase the impact in other impact categories. Study provides the other side of biodiesel life cycle impacts to the decision makers. Study gives a different direction that while making the decision about the Jatropha plantation the regional environment should be assessed carefully to ensure that Acidification, and Eutrophication will not be a problem in future. 


\section{References:}

1. S. A. Khan, Rashmi, M. Z. Hussain, S. Prasad, U. C. Banerjee. Prospects of biodiesel production from microalgae in India. Renewable and Sustainable Energy Reviews, 13 (9) (2008), 2361-2372.

2. T. V. Ramachandra, Shwetmala. Emissions from India's transport sector: Statewise synthesis. Atmospheric Environment, 43 (34) (2009), 5510-5517.

3. S. Jain, M. P. Sharma. Prospects of biodiesel from Jatropha in India: A review. Renewable and Sustainable Energy Reviews, 14 (2) (2010), 763-771.

4. A. Ghosh, D. R. Chaudhary, M. P. Reddy, S. N. Rao, J. Chikara, J. B. Pandya, J. S. Patolia, M. R. Gandhi, S. Adimurthy, N. Vaghela, S. Mishra, M. R. Rathod, A. R. Prakash, B. D. Shethia, S. C. Upadhyay, V. Balakrishna, C. R. Prakash, P. K. Ghosh. Prospects for Jatropha methyl ester (Biodiesel) in India. International Journal of Environmental Studies, 64 (6) (2007), 659-674.

5. A. Kumar, and S. Sharma. Potential non-edible oil resources as biodiesel feedstock: An Indian perspective. Renewable and Sustainable Energy Reviews, 15 (4) (2011), 1791-1800.

6. K. K. Pandey, N. Pragya, P. K. Sahoo. Life cycle assessment of small-scale high-input Jatropha biodiesel production in India. Applied Energy, 88 (12) (2011), 4831-4839.

7. A. K. Agarwal. Biofuels (alcohols and Biodiesel) applications as fuels for internal combustion engines. Progress in Energy and Combustion Science, 33 (3) (2007), 233-271.

8. K. Pramanik. Properties and use of Jatropha curcas oil and diesel fuel blends in compression ignition engine. Renewable Energy, 28 (2) (2003), 239-248.

9. M. Balat. Potential alternatives to edible oils for biodiesel production - A review of current work. Energy Conversion and Management, 52 (2) (2011), 1479-1492.

10. N. Kumar, P.B. Sharma. Jatropha curcas- A sustainable source for production of biodiesel. Journal of Scientific \& Industrial Research, 64 (2005), 883-889. IPC Code: F02B13/10, ISSN: 0022-4456.

11. G. Francis, R. Edinger, K. Becker. A concept for simultaneous wasteland reclamation, fuel production, and socio-economic development in degraded areas in India: Need, potential and perspectives of Jatropha plantation. Natural Resource Forum, 29 (1) (2005), 12-24. 
12. W.M.J. Achten, J. Almeida, V. Fobelets, E. Bolle, E. Mathijs, V.P. Singh, D.N. Tewari, L. V. Verchot, B. Muys. Life cycle assessment of Jatropha biodiesel as transportation fuel in rural India. Applied Energy, 87 (12) (2010), 3652-3660.

13. A. Ajayebi, E. Gnansounou, J.K. Raman. Comparative life cycle assessment of biodiesel from algae and Jatropha: A case study of India. Bioresource Technology, 150 (2013), 429437. doi: 10.1016/j.biortech.2013.09.118.

14. G. Reinhardt, K. Becker, R.D. Chaudhary, J. Chikara, V.E. Falenstein, G. Francis, S. Gartner, M.R. Gandhi, A. Ghosh, P. K. Ghosh, S.P.H. Makkar, J. Munch, S. J. Patolia, M. P. Reddy, N.G. Rettenmaier, C.S. Upadhyay. Basic data for Jatropha production and use. Central Salt and Marine Chemicals Research Institute, Bhavnagar (2008). <http://www.jatropha.pro/PDF\%20bestanden/en_jatropha-database-june-2008.pdf>. Accessed on 14 November, 2015.

15. A. P. Montobibo, S. Lele. Jatropha plantations for biodiesel in Tamil Nadu, India: Viability, livelihood trade-offs, and latent conflict. Ecological Economics, 70 (2) (2010), 189-195.

16. L. Axelsson, M. Franzen, M. Ostwald, G. Berndes, N. Ravidranath. Performance of Jatropha Biodiesel production and its environmental and socio-economic impacts - A case study in Southern India. World Renewable Energy Congress 2011 - Sweden (2011), 24702477.

17. S. Kumar, J. Singh, S. M. Nanoti, M. O. Garg. A comprehensive life cycle assessment (LCA) of Jatropha biodiesel production in India. Bioresource Technology, 110 (2012), $723-729$.

18. S. S. Nevase, S. R. Gadge, A. K. Dubey, B. D. Kadu. Economics of biodiesel production from Jatropha oil. Journal of Agricultural Technology, 8 (2) (2012), 657-662.

19. Maruti Suzuki Website, Mileage of Celerio Vehicle. http://www.marutisuzuki.com/celerio.aspx. Accessed on 19 March 2016.

20. M. Whitaker, G. Heath. Life Cycle Assessment of the Use of Jatropha biodiesel in Indian Locomotives. Technical report NREL/TP-6A2-44428 (2009). <http://www.nrel.gov/docs/fy09osti/44428.pdf>. Accessed on 17 December, 2015.

21. 2006 IPCC Guidelines for National Greenhouse Gas Inventories, Volume 5 (2006). <http://www.ipcc-nggip.iges.or.jp/public/2006gl/vol5.html>. Accessed on 29 October, 2015. 
22. Moterbeam. Relation between actual and claimed mileage (2014). $<$ http://www.motorbeam.com/2014/03/general/arai-mileage-test-procedure-doesnt-showreal-world-fuel-efficiency/>. Accessed on 20 March 2016.

23. Centre Pollution Control Board, Status of Pollution Generated from Road Transport in Six Mega Cities, Ministry of Environment, Forest and Climate Change (2015). $<$ http://cpcb.nic.in/upload/NewItems/NewItem_215_Report_Status_RoadTransport_SixCit ies.pdf>

24. Air Quality Expert Group, Road transport biofuels: impact on UK air quality (2011). https://uk-air.defra.gov.uk/assets/documents/110322_AQEG_Biofuels_advice_note.pdf

25. Pacific Biodiesel Change in fuel economy because of biodiesel blends. URL $<$ http://www.biodiesel.com/biodiesel/benefits/>. Accessed on 20 March, 2016.

26. Change in fuel economy because of biodiesel blends. Official U.S. government source of information for fuel economy information. <https://www.fueleconomy.gov/feg/biodiesel.shtml>. Accessed on 20 March 2016

27. L. G. Anderson. Effects of biodiesel fuel use on vehicle emissions. World Renewable Energy Congress 2011 - Sweden (2011), 3645 - 3652.

28. CSE (Centre for Science and Environment), challenge of the new balance, chapter 5 (2009). $<$ http://www.cseindia.org/content/challenge-new-balance>. Accessed on 24 December, 2015.

29. M. Skowrońska, T. Filipek. Life cycle assessment of fertilizers: a review. International Agrophysics, 28 (1) (2014), 101-110.

30. A. Kool, M. Marinussen, H. Blonk. GHG emissions of N, P and K fertilizer production. LCI data for the calculation tool for greenhouse gas emissions of feed production and utilization $<$ http://blonkconsultants.n1/upload/pdf/PDV\%20rapporten/fertilizer_production\%20D03. pdf >. Accessed on 15 January, 2016.

31. International Energy Agency, India energy outlook, world energy outlook social report (2015).

http://www.worldenergyoutlook.org/media/weowebsite/2015/IndiaEnergyOutlook_WEO 2015.pdf 


\section{Figures:}

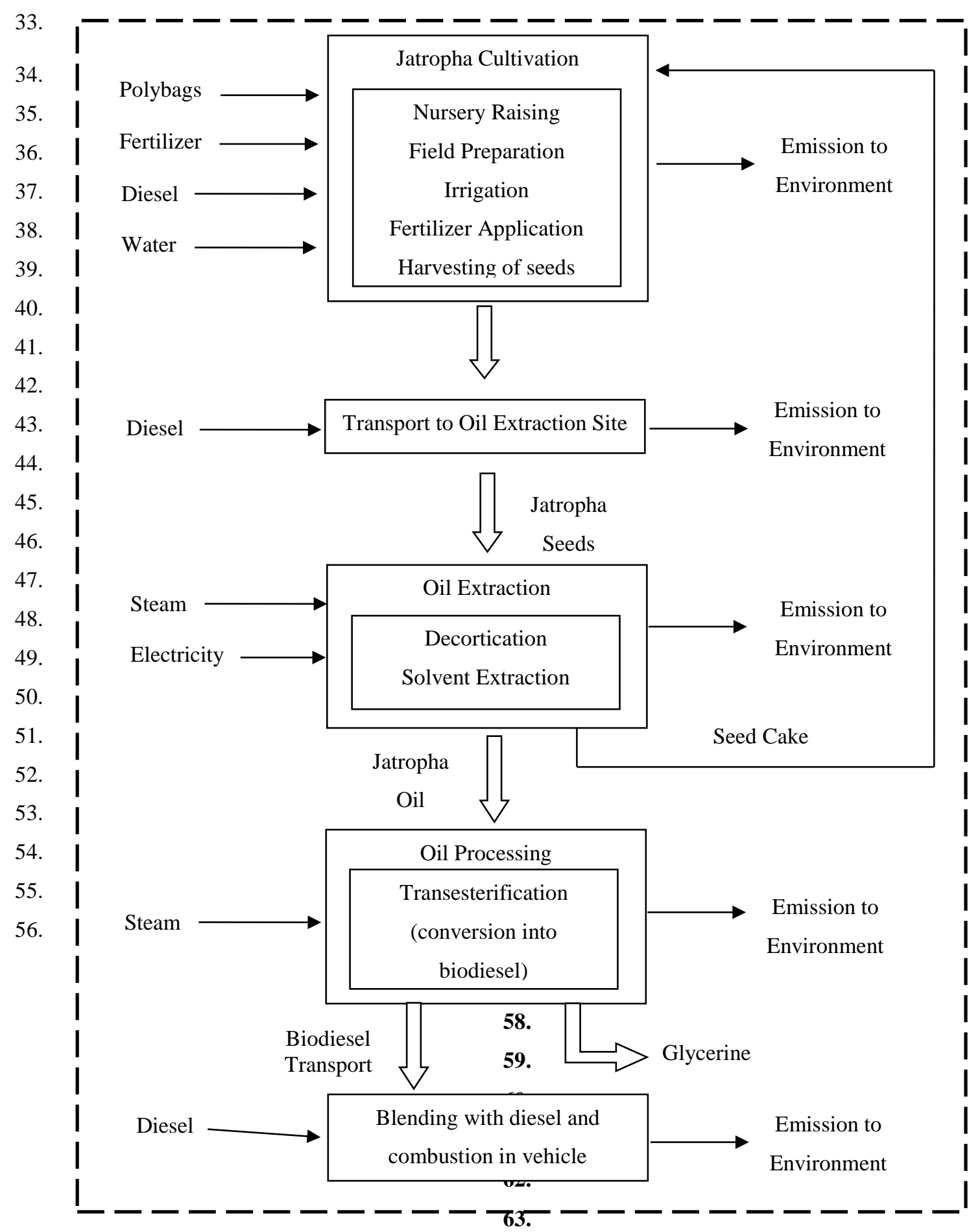

Figure 1: Representation of system boundary for biodiesel production from Jatropha 
a

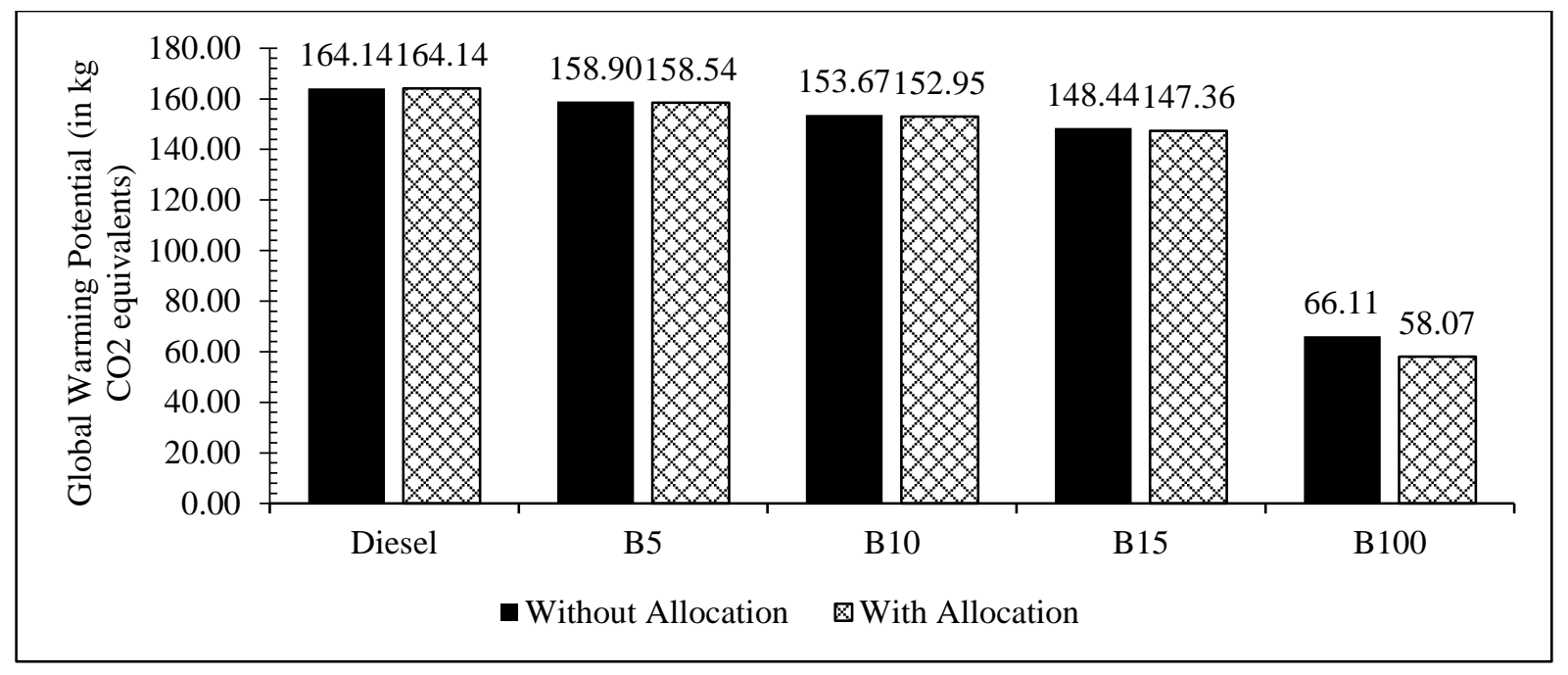

a) Global Warming Potential (Excluding Biogenic Fraction)

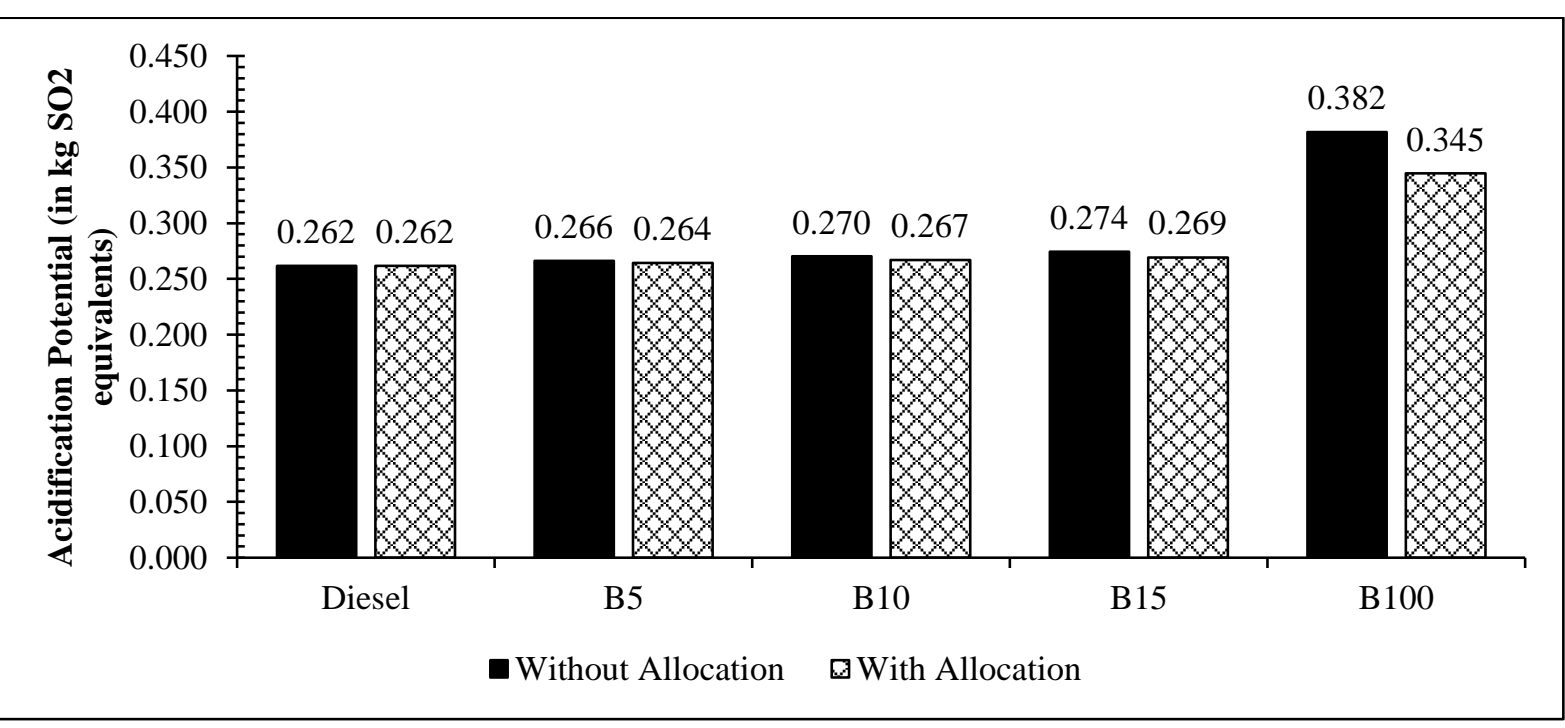

b) Acidification Potential

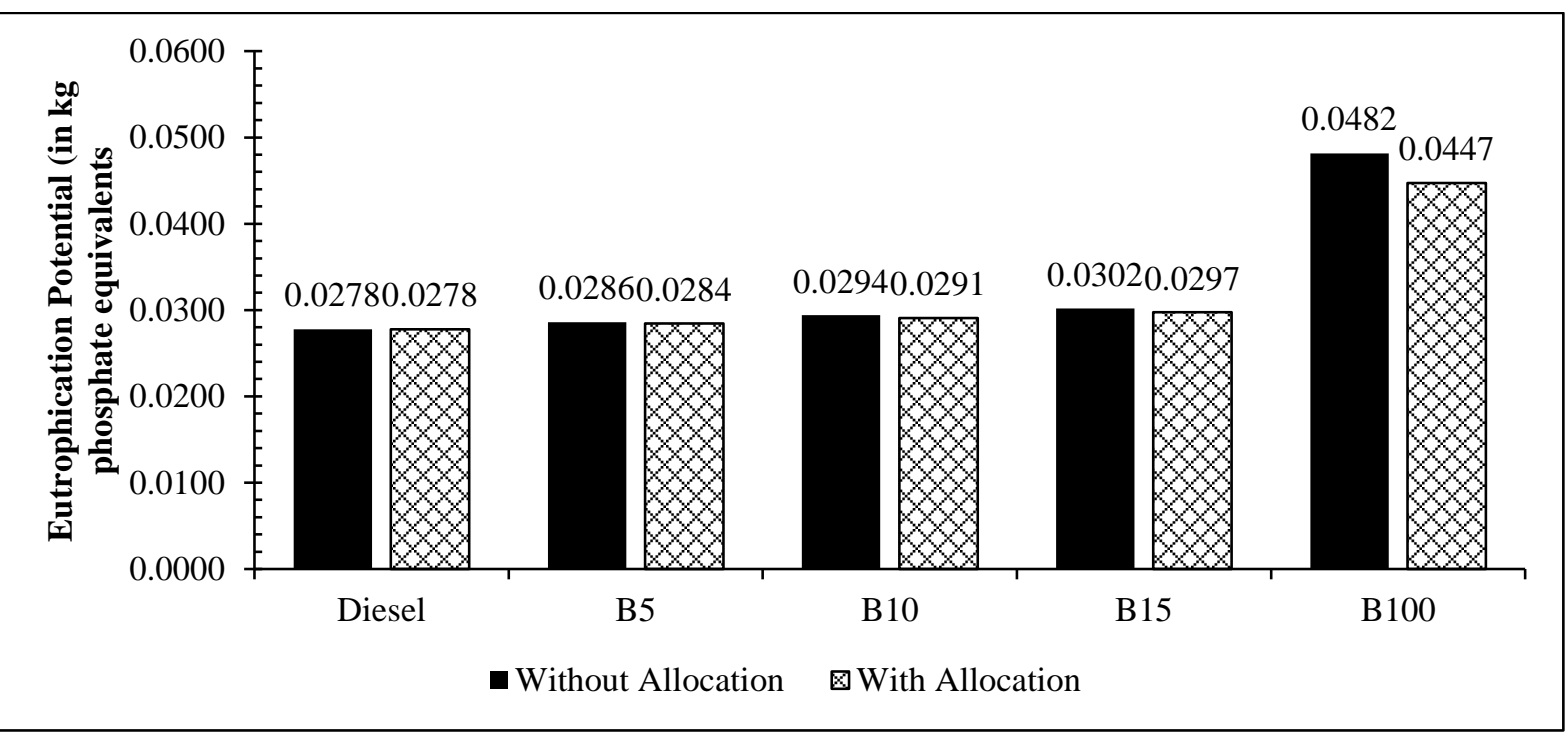

c) Eutrophication Potential 


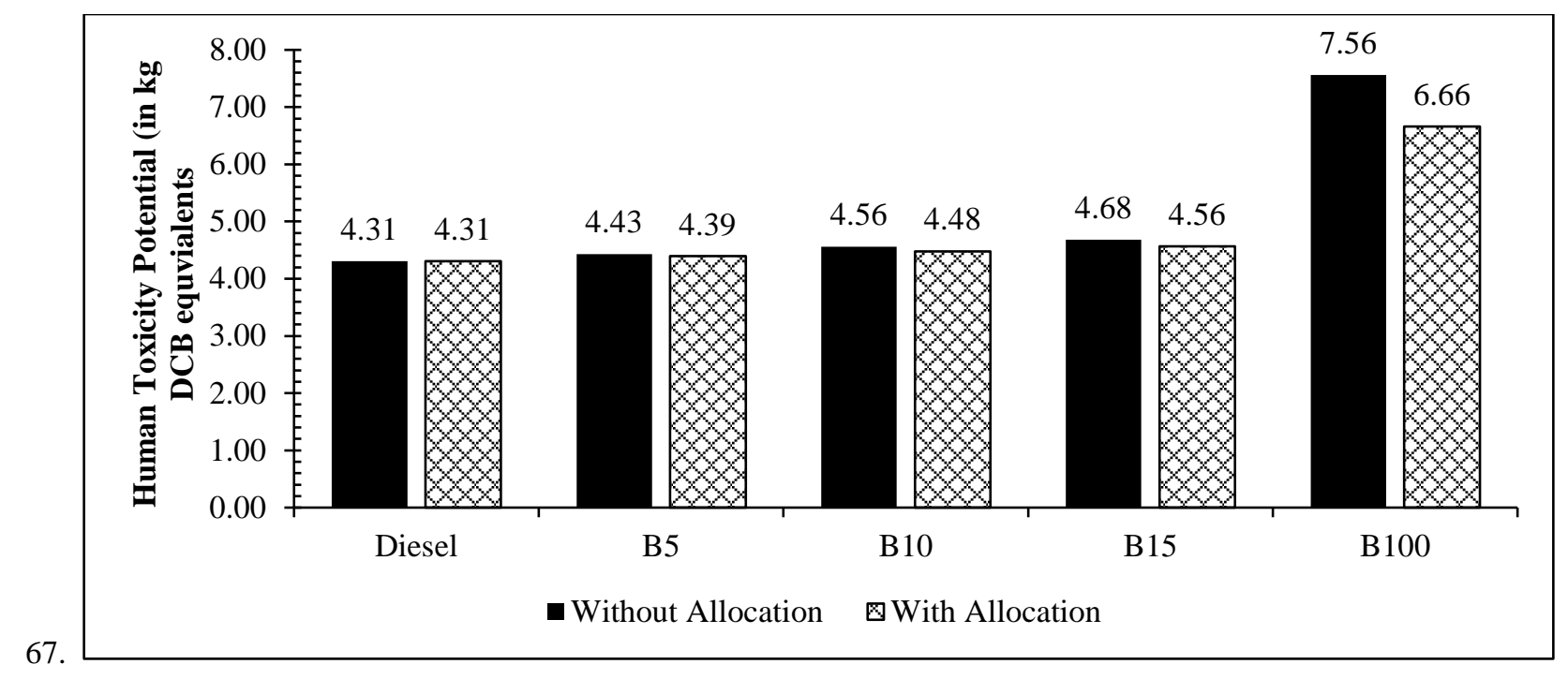

d) Human Toxicity Potential

Figure 2: Environmental Impacts of different blends of biodiesel and diesel for functional unit ' $1000 \mathrm{~km}$ travel distance by a passenger car using biodiesel'

68. 


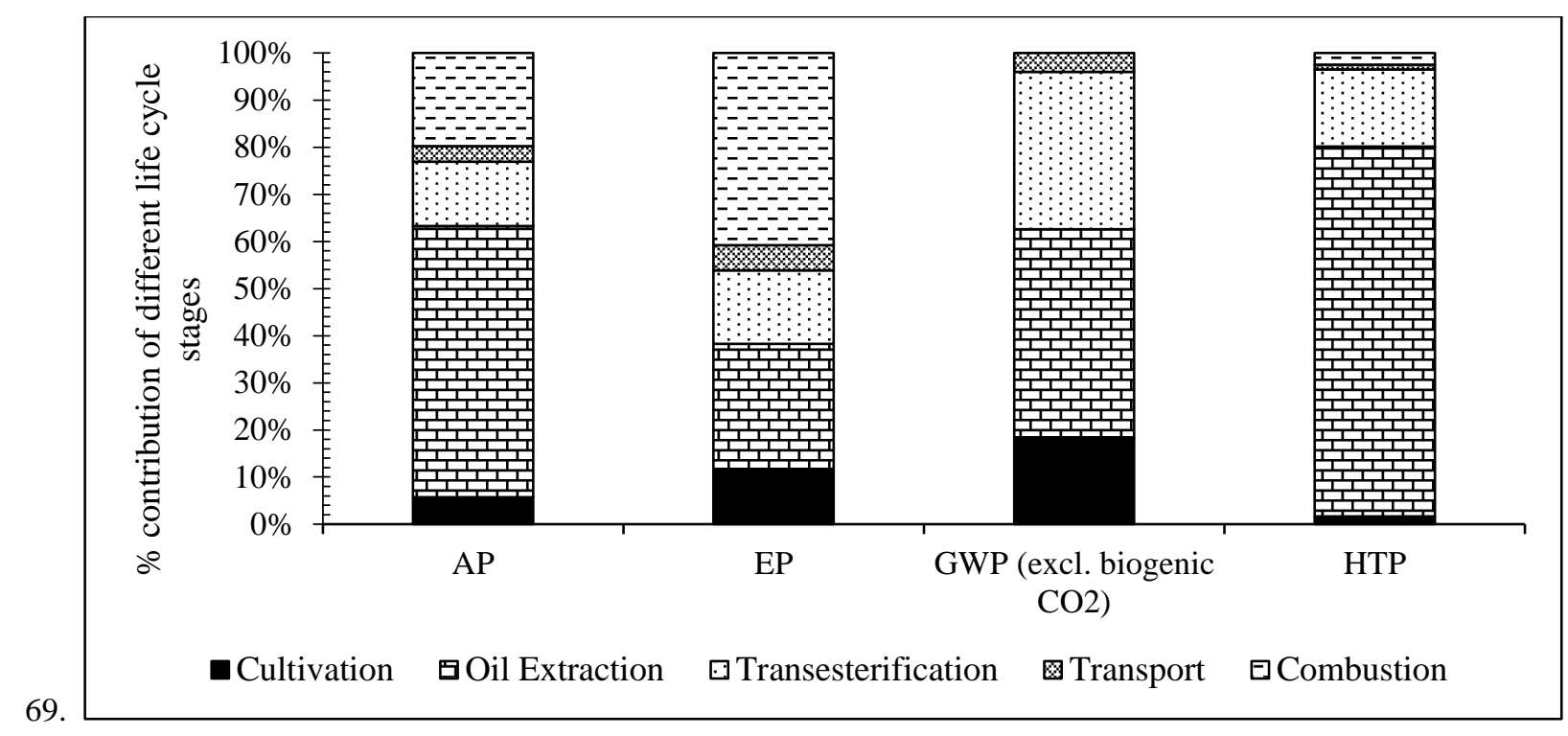

Figure 3: Contribution of all life cycle stages in overall life cycle emissions 


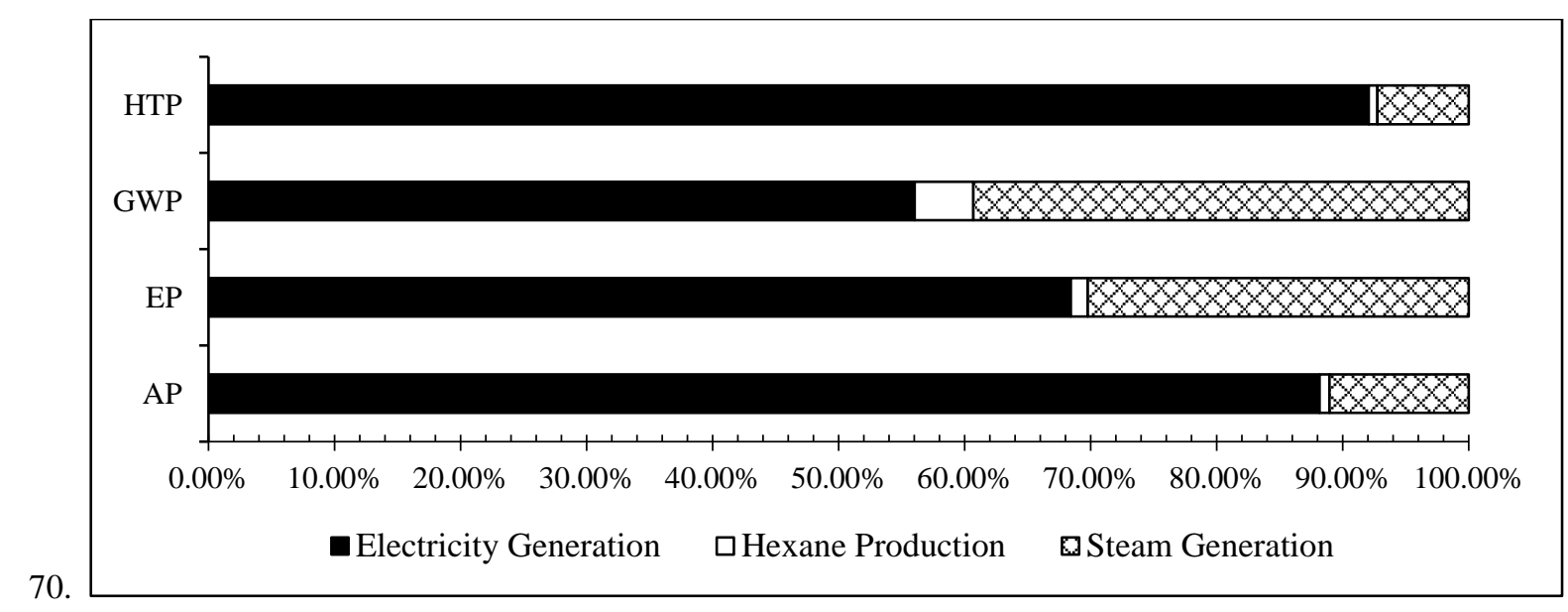

Figure 4: Contribution of impacts coming from electricity generation in oil extraction phase

71. 
Tables:

Table 1: Inventory for cultivation phase

\begin{tabular}{|c|c|}
\hline Input/output Parameter & Value \\
\hline Plantation density ${ }^{\mathrm{a}, \mathrm{b}, \mathrm{c}}$ & 2500 Trees/ha \\
\hline Germination rate in nursery ${ }^{c}$ & $70 \%$ \\
\hline Polyethene required ${ }^{\mathrm{c}}$ & $10 \mathrm{gm} / \mathrm{polybag}$ \\
\hline $\begin{array}{l}\text { Seed yield }{ }^{\text {a }} \\
\text { (decorticated seeds) }\end{array}$ & $1418 \mathrm{~kg} / \mathrm{ha}$ \\
\hline Nitrogen $^{a}$ & 48 kg/ha-yr. \\
\hline $\mathrm{P}_{2} \mathrm{O}_{5}{ }^{\mathrm{a}}$ & 19 kg/ha-yr. \\
\hline $\mathrm{K}_{2} \mathrm{O}^{\mathrm{a}}$ & 53 kg/ha-yr. \\
\hline Urea for Nursery raising $^{c}$ & $\begin{array}{l}25 \mathrm{~kg} / 3500 \text { plants in } \\
\text { nursery }\end{array}$ \\
\hline Water for irrigation ${ }^{c}$ & 300000 L/ha-yr. \\
\hline Diesel for cultivation ${ }^{a}$ & 55 L/ha-yr. \\
\hline $\begin{array}{l}\text { Diesel for irrigation }{ }^{\text {a }} \\
\text { (Using pump having capacity to pump } \\
7500 \mathrm{~L} \text { water/hr) }\end{array}$ & $1.25 \mathrm{~L} / \mathrm{hr}$ \\
\hline Pesticides $^{d}$ & 2.6 kg/ha-yr. \\
\hline $\mathrm{N}_{2} \mathrm{O}$ release from field ${ }^{\mathrm{e}}$ & $0.01 \mathrm{~kg} / \mathrm{kg}-\mathrm{N}$ used \\
\hline
\end{tabular}

Source: a- [14]; b- [20]; c- [6]; d- [17]; e- [21] 
Table 2: Inventory for oil extraction phase

\begin{tabular}{|c|c|}
\hline Input/output Parameter & Value \\
\hline $\begin{array}{l}\text { Electricity for decorticator } \\
\text { a }\end{array}$ & $\begin{array}{l}10 \mathrm{kwh} / \mathrm{ton} \text { of seeds } \\
\text { input }\end{array}$ \\
\hline Steam for oil extraction $b, c$ & $\begin{array}{l}280 \mathrm{~kg} / \mathrm{ton} \text { of seeds } \\
\text { input }\end{array}$ \\
\hline $\begin{array}{l}\text { Electricity for } \\
\text { extraction } b, c\end{array}$ & $\begin{array}{l}55 \mathrm{kwh} / \mathrm{ton} \text { of seeds } \\
\text { input }\end{array}$ \\
\hline Hexane for oil extraction ${ }^{b, c}$ & $4 \mathrm{~kg} /$ ton of seeds \\
\hline Oil content of seeds ${ }^{c, d, e}$ & $35 \%$ \\
\hline Oil extraction efficiency ${ }^{c}$ & $91 \%$ \\
\hline
\end{tabular}


Table 3: Oil processing (Transesterification) phase inventory analysis

\begin{tabular}{ll}
\hline \multicolumn{1}{c}{ Input/output Parameter } & \multicolumn{1}{c}{ Value } \\
\hline Methanol $^{\text {a }}$ & $117 \mathrm{~kg} /$ ton of oil \\
$\mathrm{NaOH}^{\mathrm{a}}$ & $12.8 \mathrm{~kg} /$ ton of oil \\
Electricity $^{\mathrm{a}, \mathrm{b}}$ & $36 \mathrm{kwh} / \mathrm{ton}$ of oil \\
Steam $^{\mathrm{a}, \mathrm{b}}$ & $660 \mathrm{~kg} / \mathrm{ton}$ of oil \\
Glycerine fraction $^{\mathrm{a}}$ & $0.125 \mathrm{~kg} / \mathrm{kg}$ of biodiesel \\
Transesterification efficiency $_{\text {a,b,c }}$ & $95 \%$ \\
\hline
\end{tabular}

a- [17]; b- [20]; c- [6] 
Table 4: Emission factor for BS IV diesel Vehicle

\begin{tabular}{lllllll}
\hline \multirow{2}{*}{ Vehicle Type } & & \multirow{2}{*}{ Vintag } & \multicolumn{4}{c}{ Emission Factors $(\mathbf{g} / \mathbf{k m})$} \\
\cline { 3 - 7 } & & e & CO & HC & NOx & PM \\
\hline $\begin{array}{l}\text { Passenger } \\
(<1600 \mathrm{cc})\end{array}$ & Cars & BSIV & 0.047 & 0.048 & 0.140 & $\begin{array}{l}0.00 \\
8\end{array}$ \\
\hline
\end{tabular}

Source: CPCB [23] 
Table 5: Emission scaling factors for biodiesel over reference fuel diesel

\begin{tabular}{ccccc}
\hline $\begin{array}{c}\text { Biodiesel } \\
\text { Blends }\end{array}$ & CO & HC & NOx & PM \\
\hline B5 & 0.99 & 0.97 & 1.00 & 0.95 \\
B10 & 0.98 & 0.95 & 1.00 & 0.91 \\
B15 & 0.97 & 0.92 & 1.00 & 0.86 \\
B100 & 0.66 & 0.31 & 1.08 & 0.62 \\
\hline Source: Air Quality Expert Group [24]
\end{tabular}


Table 6: Emission factors for all input/output materials considered in the study

\begin{tabular}{|c|c|c|c|c|c|c|}
\hline \multirow[b]{2}{*}{$\begin{array}{l}\text { Object } \\
\text { Name }\end{array}$} & \multirow[b]{2}{*}{ Unit } & \multicolumn{4}{|c|}{ Emission Factors } & \multirow[b]{2}{*}{ Source } \\
\hline & & $\begin{array}{c}\text { GWP } \\
\text { (kg CO} 2 \\
\text { eq.) }\end{array}$ & $\begin{array}{l}\mathrm{AP}(\mathrm{g} \\
\mathrm{SO}_{4} \\
\text { eq. })\end{array}$ & $\begin{array}{c}\text { EP (g } \\
\text { Phosphate } \\
\text { eq.) }\end{array}$ & $\begin{array}{c}\text { HTP } \\
(\mathrm{kg} \\
\text { DCB } \\
\text { eq. })\end{array}$ & \\
\hline Urea & Per kg & 0.57 & 5.3 & 0.54 & - & {$[28,29]$} \\
\hline $\mathrm{K}_{2} \mathrm{O}$ & Per kg & 1.47 & - & - & - & [30] \\
\hline $\mathrm{P}_{2} \mathrm{O}_{5}$ & Per kg & 1.66 & 8.1 & 0.74 & - & $\begin{array}{l}{[30]} \\
{[29]}\end{array}$ \\
\hline Pesticide & Per kg & 8.85 & 22.9 & 2.3 & 0.297 & Gabi Database \\
\hline Diesel & Per Litre & 0.561 & 4.41 & 0.216 & 0.095 & Gabi Database \\
\hline Polythene & Per kg & 1.89 & 3.15 & 0.344 & 0.072 & Gabi Database \\
\hline Electricity & Per MJ & 1.39 & 16.4 & 0.742 & 0.464 & Gabi Database \\
\hline Hexane & Per kg & 2.07 & 2.65 & 0.260 & 0.061 & Gabi Database \\
\hline $\begin{array}{l}\text { Steam } \\
\text { from } \\
\text { natural gas }\end{array}$ & Per MJ & 0.080 & 0.17 & 0.027 & 0.003 & Gabi Database \\
\hline $\mathrm{NaOH}$ & Per kg & 1.03 & 2.88 & 0.38 & 0.037 & Gabi Database \\
\hline Landfilling & $\begin{array}{l}\text { Per kg of } \\
\text { waste }\end{array}$ & 0.737 & 0.245 & 0.914 & 0.002 & Gabi Database \\
\hline $\begin{array}{l}\text { Transport } \\
\text { by truck } \\
\text { (12.4-ton } \\
\text { payload) }\end{array}$ & $\begin{array}{l}\text { Per kg } \\
\text { Cargo for } \\
100 \mathrm{~km} \\
\text { distance }\end{array}$ & 0.009 & 0.040 & 0.008 & 0.0003 & Gabi Database \\
\hline $\begin{array}{l}\text { Transport } \\
\text { by truck } \\
\text { (18.4-ton } \\
\text { payload) }\end{array}$ & $\begin{array}{c}\text { Per kg } \\
\text { Cargo for } \\
100 \mathrm{~km} \\
\text { distance }\end{array}$ & 0.006 & 0.028 & 0.006 & 0.0002 & Gabi Database \\
\hline
\end{tabular}


Table 7: Sensitivity analysis of diesel life cycle plan

\begin{tabular}{|c|c|c|c|c|c|c|c|c|}
\hline \multirow{2}{*}{$\begin{array}{c}\text { Parameter/ } \\
\text { Variation }\end{array}$} & \multicolumn{2}{|c|}{ GWP } & \multicolumn{2}{|c|}{$\mathbf{A P}$} & \multicolumn{2}{|c|}{ EP } & \multicolumn{2}{|c|}{ HTP } \\
\hline & $-10 \%$ & $+10 \%$ & $-10 \%$ & $+10 \%$ & $-10 \%$ & $+10 \%$ & $-10 \%$ & $+10 \%$ \\
\hline $\begin{array}{l}\text { Carbon } \\
\text { Monoxide } \\
\text { emission factor }\end{array}$ & $0.00 \%$ & $0.00 \%$ & $0.00 \%$ & $0.00 \%$ & $0.00 \%$ & $0.00 \%$ & $0.00 \%$ & $0.00 \%$ \\
\hline $\begin{array}{l}\mathrm{CO}_{2} \text { emission } \\
\text { factor of diesel }\end{array}$ & $-8.50 \%$ & $8.50 \%$ & $0.00 \%$ & $0.00 \%$ & $0.00 \%$ & $0.00 \%$ & $0.00 \%$ & $0.00 \%$ \\
\hline $\begin{array}{l}\text { Distance from } \\
\text { refinery }\end{array}$ & $-0.01 \%$ & $0.01 \%$ & $\begin{array}{l}- \\
0.04 \%\end{array}$ & $0.04 \%$ & $-\overline{0}$ & $0.07 \%$ & $-\overline{0.014 \%}$ & $0.014 \%$ \\
\hline $\begin{array}{l}\text { Hydrocarbon } \\
\text { emission factor }\end{array}$ & $0.00 \%$ & $0.00 \%$ & $0.00 \%$ & $0.00 \%$ & $0.00 \%$ & $0.00 \%$ & $-\overline{0.002 \%}$ & $0.002 \%$ \\
\hline $\begin{array}{l}\text { NOx emission } \\
\text { factor of diesel }\end{array}$ & $0.00 \%$ & $0.00 \%$ & $2.67 \%$ & $2.67 \%$ & $6.55 \%$ & $6.55 \%$ & $-0.39 \%$ & $0.39 \%$ \\
\hline $\begin{array}{l}\text { PM emission } \\
\text { factor }\end{array}$ & $0.00 \%$ & $0.00 \%$ & $0.00 \%$ & $0.00 \%$ & $0.00 \%$ & $0.00 \%$ & $-0.02 \%$ & $0.02 \%$ \\
\hline
\end{tabular}

*highlighted value indicates sensitive parameters in the respective impact category 
Table 8: Sensitivity analysis results to identify parameters most affecting the model

\begin{tabular}{|c|c|c|c|c|c|c|c|c|}
\hline \multirow{2}{*}{ Parameter/variation } & \multicolumn{2}{|c|}{ GWP } & \multicolumn{2}{|c|}{ AP } & \multicolumn{2}{|c|}{ EP } & \multicolumn{2}{|c|}{ HTP } \\
\hline & $-10 \%$ & $10 \%$ & $-10 \%$ & $10 \%$ & $-10 \%$ & $10 \%$ & $-10 \%$ & $10 \%$ \\
\hline Fertilizer application years & $-1.56 \%$ & $1.56 \%$ & $-0.50 \%$ & $0.50 \%$ & $-1.06 \%$ & $1.06 \%$ & $-0.11 \%$ & $0.11 \%$ \\
\hline $\mathrm{CO}$ emission factor for biodiesel & $0.00 \%$ & $0.00 \%$ & $0.00 \%$ & $0.00 \%$ & $0.00 \%$ & $0.00 \%$ & $0.00 \%$ & $0.00 \%$ \\
\hline $\mathrm{CO}_{2}$ emission factor for biodiesel & $0.00 \%$ & $0.00 \%$ & $0.00 \%$ & $0.00 \%$ & $0.00 \%$ & $0.00 \%$ & $0.00 \%$ & $0.00 \%$ \\
\hline Diesel used in farm tilling & $-0.15 \%$ & $0.15 \%$ & $-0.03 \%$ & $0.03 \%$ & $-0.01 \%$ & $0.01 \%$ & $-0.03 \%$ & $0.03 \%$ \\
\hline Diesel used in Irrigation & $-0.42 \%$ & $0.42 \%$ & $-0.08 \%$ & $0.08 \%$ & $-0.04 \%$ & $0.04 \%$ & $-0.09 \%$ & $0.09 \%$ \\
\hline Distance from farm to site & $-0.05 \%$ & $0.05 \%$ & $-0.04 \%$ & $0.04 \%$ & $-0.06 \%$ & $0.06 \%$ & $-0.01 \%$ & $0.01 \%$ \\
\hline Distance from site to retailer & $-0.36 \%$ & $0.36 \%$ & $-0.29 \%$ & $0.29 \%$ & $-0.47 \%$ & $0.47 \%$ & $-0.09 \%$ & $0.09 \%$ \\
\hline Electricity used in decortication & $-0.58 \%$ & $0.58 \%$ & $-1.18 \%$ & $1.18 \%$ & $-0.42 \%$ & $0.42 \%$ & $-1.68 \%$ & $1.68 \%$ \\
\hline Electricity used in solvent extraction & $-1.90 \%$ & $1.90 \%$ & $-3.89 \%$ & $3.89 \%$ & $-1.39 \%$ & $1.39 \%$ & $-5.55 \%$ & $5.55 \%$ \\
\hline Electricity used in transesterification & $-0.40 \%$ & $0.40 \%$ & $-0.82 \%$ & $0.82 \%$ & $-0.29 \%$ & $0.29 \%$ & $-1.16 \%$ & $1.16 \%$ \\
\hline Hydrocarbon emission factor for diesel & $0.00 \%$ & $0.00 \%$ & $0.00 \%$ & $0.00 \%$ & $0.00 \%$ & $0.00 \%$ & $0.00 \%$ & $0.00 \%$ \\
\hline Hexane use & $-0.21 \%$ & $0.21 \%$ & $-0.05 \%$ & $0.05 \%$ & $-0.04 \%$ & $0.04 \%$ & $-0.05 \%$ & $0.05 \%$ \\
\hline $\mathrm{K}_{2} \mathrm{O}$ use & $-0.21 \%$ & $0.21 \%$ & $0.00 \%$ & $0.00 \%$ & $0.00 \%$ & $0.00 \%$ & $0.00 \%$ & $0.00 \%$ \\
\hline Life cycle years of Jatropha & $2.05 \%$ & $-1.68 \%$ & $0.64 \%$ & $-0.52 \%$ & $1.30 \%$ & $-1.07 \%$ & $0.18 \%$ & $-0.15 \%$ \\
\hline Methanol emission factor & $-1.85 \%$ & $1.85 \%$ & $-0.04 \%$ & $0.04 \%$ & $-1.17 \%$ & $1.17 \%$ & $-0.02 \%$ & $0.02 \%$ \\
\hline Urea emission factor & $-0.79 \%$ & $0.79 \%$ & $-0.30 \%$ & $0.30 \%$ & $-0.95 \%$ & $0.95 \%$ & $0.00 \%$ & $0.00 \%$ \\
\hline $\mathrm{NaOH}$ use & $-0.18 \%$ & $0.18 \%$ & $-0.06 \%$ & $0.06 \%$ & $-0.18 \%$ & $0.18 \%$ & $-0.04 \%$ & $0.04 \%$ \\
\hline NOx emission factor for diesel & $0.00 \%$ & $0.00 \%$ & $-1.98 \%$ & $1.98 \%$ & $-4.08 \%$ & $4.08 \%$ & $-0.24 \%$ & $0.24 \%$ \\
\hline $\mathrm{P}_{2} \mathrm{O}_{5}$ use & $-0.08 \%$ & $0.08 \%$ & $-0.08 \%$ & $0.08 \%$ & $-0.05 \%$ & $0.05 \%$ & $0.00 \%$ & $0.00 \%$ \\
\hline Particulate emission factor for diesel & $0.00 \%$ & $0.00 \%$ & $0.00 \%$ & $0.00 \%$ & $0.00 \%$ & $0.00 \%$ & $-0.01 \%$ & $0.01 \%$ \\
\hline Seed yield of Jatropha & $2.05 \%$ & $-1.68 \%$ & $0.64 \%$ & $-0.52 \%$ & $1.30 \%$ & $-1.07 \%$ & $0.18 \%$ & $-0.15 \%$ \\
\hline Steam used in oil extraction & $-1.74 \%$ & $1.74 \%$ & $-0.64 \%$ & $0.64 \%$ & $-0.80 \%$ & $0.80 \%$ & $-0.57 \%$ & $0.57 \%$ \\
\hline Steam used in transesterification & $-1.31 \%$ & $1.31 \%$ & $-0.48 \%$ & $0.48 \%$ & $-0.61 \%$ & $0.61 \%$ & $-0.43 \%$ & $0.43 \%$ \\
\hline
\end{tabular}

* Highlighted values indicate the top 5 parameters most affecting the model in corresponding impact categories. 
Table 9: Change in life cycle environmental impacts under six different scenario of Jatropha life cycle span for functional unit ' $1000 \mathbf{~ k m}$ travel distance by a passenger car using biodiesel'

\begin{tabular}{lcccccc}
\hline \multirow{2}{*}{$\begin{array}{l}\text { Impact } \\
\text { Category }\end{array}$} & \multicolumn{6}{c}{ Scenarios for plantation life cycle years } \\
\cline { 2 - 7 } & 20 years & 16 years & 12 years & 8 years & 4 years & 1 year \\
\hline GWP & $-59.61 \%$ & $-57.76 \%$ & $-54.65 \%$ & $-48.48 \%$ & $-29.84 \%$ & $-2.21 \%$ \\
AP & $51.20 \%$ & $53.49 \%$ & $57.17 \%$ & $64.06 \%$ & $85.66 \%$ & $115.07 \%$ \\
EP & $73.72 \%$ & $78.74 \%$ & $87.53 \%$ & $104.28 \%$ & $155.34 \%$ & $215.62 \%$ \\
HTP & $73.18 \%$ & $73.71 \%$ & $75.04 \%$ & $77.43 \%$ & $84.60 \%$ & $101.87 \%$ \\
\hline
\end{tabular}

* Negative sign implies reduction in environmental impacts

Units: GWP - kg CO2 equivalents, AP- kg SO2 equivalents, EP-kg Phosphate equivalents, HTP- kg DCB equivalents 
Table 10: Change in life cycle environmental impacts under three different scenario of seed yields for functional unit ' $1000 \mathrm{~km}$ travel distance by a passenger car using biodiesel'

\begin{tabular}{cccccccc}
\hline $\begin{array}{c}\text { Impact } \\
\text { Category/ } \\
\text { Scenario }\end{array}$ & \multicolumn{3}{c}{ Seed yield } & & \multicolumn{3}{c}{$\begin{array}{c}\text { \% increase/decrease in impacts } \\
\text { over reference fuel diesel }\end{array}$} \\
\cline { 2 - 4 } \cline { 7 - 8 } & 450 & 2363 & 5900 & & Scenario & Scenario & Scenario \\
& $\mathrm{kg} / \mathrm{ha}$ & $\mathrm{kg} / \mathrm{ha}$ & $\mathrm{kg} / \mathrm{ha}$ & & 1 & 2 & 3 \\
\hline GWP & 118.36 & 66.14 & 58.834 & & $-27.72 \%$ & $-59.61 \%$ & $-64.07 \%$ \\
$\mathrm{AP}$ & 0.47 & 0.38 & 0.37 & & $87.96 \%$ & $51.20 \%$ & $46.14 \%$ \\
$\mathrm{EP}$ & 0.072 & 0.048 & 0.045 & & $160.37 \%$ & $73.72 \%$ & $61.58 \%$ \\
$\mathrm{HTP}$ & 8.10 & 7.56 & 7.49 & & $85.40 \%$ & $73.18 \%$ & $71.32 \%$ \\
\hline
\end{tabular}

Units: GWP - kg CO2 equivalents, AP- kg SO2 equivalents, EP-kg Phosphate equivalents, HTP- kg DCB equivalents, 
Table 11: Change in life cycle environmental impacts of $\mathrm{B} 100$ under three different scenario of electricity emission intensity for functional unit ' $1000 \mathrm{~km}$ travel distance by a passenger car using biodiesel'

\begin{tabular}{|c|c|c|c|c|c|c|}
\hline \multirow{2}{*}{$\begin{array}{l}\text { Impact } \\
\text { Category/ } \\
\text { Scenario }\end{array}$} & \multicolumn{3}{|c|}{$\begin{array}{c}\text { Electricity emission intensity } \\
\text { reduction scenarios }\end{array}$} & \multicolumn{3}{|c|}{$\begin{array}{c}\text { \% increase/decrease in impacts } \\
\text { over reference fuel diesel }\end{array}$} \\
\hline & Scenario 1 & $\begin{array}{l}\text { Scenario } \\
2\end{array}$ & Scenario 3 & $\begin{array}{c}\text { Scenario } \\
1\end{array}$ & Scenario 2 & Scenario 3 \\
\hline GWP & 66.14 & 63.26 & 60.41 & $-59.61 \%$ & $-61.37 \%$ & $-63.11 \%$ \\
\hline $\mathrm{AP}$ & 0.38 & 0.34 & 0.31 & $51.20 \%$ & $37.84 \%$ & $24.48 \%$ \\
\hline $\mathrm{EP}$ & 0.048 & 0.047 & 0.045 & $73.72 \%$ & $68.25 \%$ & $62.76 \%$ \\
\hline HTP & 7.56 & 6.61 & 5.66 & $73.18 \%$ & $51.33 \%$ & $29.54 \%$ \\
\hline
\end{tabular}

Units: GWP - kg CO2 equivalents, AP- kg SO2 equivalents, EP-kg Phosphate equivalents, HTP- kg DCB equivalents, 